\title{
Samtaler med eldre om livets sluttfase
}

\author{
Informasjon til beboere på sykehjem om behandling i livets sluttfase gir trygghet og autonomi.
}

A rtikkelen er resultat av en fordypningsoppgave ved videreutdanningen $i$ aldring og eldreomsorg ved Institutt for helsefag, Universitetet i Stavanger, og samhandlingsprosjektet mellom Stavanger universitetssykehus (SUS) og Lunde bo- og aktivitetssenter, sykehjemsavdeling. Artikkelen bygger på intervju med sykepleierne som jevnlig har deltatt i planlegging av behandlingen og informasjonssamtalene med eldre pasienter på Lunde-sykehjemmet. Innføring av informasjonssamtaler med eldre pasienter

\section{Hovedbudskap}

I denne studien er sykepleiere med erfaring fra informasjonssamtaler med eldre pasienter i sykehjem og deres pårørende blitt intervjuet. Tema for samtalene var autonomi ved valg av behandling i livets sluttfase. Resultatet viser at disse samtalene har fremmet både pasientenes autonomi og skapt mer trygghet både for pasienter, pårørende og helsepersonell.

\section{Søkeord}

Les mer og finn litteraturhenvisninger på våre nettsider. । Eldre \Sykehjem । Død IInformasjon og deres pårørende på Lunde-sykehjemmet om preferanser til behandling i livets sluttfase har fremmet pasientenes autonomi og skapt bedre trygghet i behandlingssituasjoner.

\section{Paternalistiske holdninger}

Gjennomgang av forskningslitteratur fra USA og Belgia viser at kun mellom 15,7-17 prosent av eldre pasienter blir spurt om sine preferanser om behandling ved livets slutt $(1,2)$. I samsvar med disse funnene har en ny norsk studie (3) avdekket paternalistiske holdninger blant leger når det gjelder å velge den beste behandlingen av eldre pasienter i livets sluttfase på norske sykehjem. Studien viste at den eldre pasientens autonomi ikke er ivaretatt i henhold til Pasientrettighetsloven (4), og at pasienter blir behandlet som inkompetente til å ta slike avgjørelser, selv om de er i stand til å gjøre det. Ifølge studien er det behov for bedre rutiner for beslutningsprosesser vedrørende behandling gjennom mer koordinering og involvering av både pasienter, pårørende og helsepersonell. Pasientens rett til å foreta autonome valg om egen behandling, inkludert behandling ved livets slutt, er solid underbygget $\mathrm{i}$ juridiske dokumenter både nasjonalt og internasjonalt (4, $5,6,7,8,9,10)$.

\section{Unngå sykehusinnleggelser}

Prosjektet med informasjonssamtalene på Lunde startet i 2008. I 2008-2009 var Astrid Frøysland ansatt som praksiskonsulent ved SUS, og gjennomførte et prosjekt vedrørende uverdige eller unødvendige innleggelser av sykehjemspasienter i sykehus. Hypotesen ved starten av prosjektet var at gode og dokumenterte samtaler med pasient og pårørende gjennom hele sykdomsforløpet kan bidra til å unngå unødvendige sykehusinnleggelser. I løpet av prosjektperioden og årene etter har leger, sykepleiere, pasienter og pårørende hatt gode erfaringer med informasjonssamtalene. Ønsket er at også sykehuset innkaller pasient og pårørende til samtale før utskriving til sykehjemmet, når man anser det som nødvendig, for å avklare hva sykehuset kan behandle. Dette er god samhandling for pasienten.

\section{Intervjuer}

Formålet med å intervjue sykepleiere som har deltatt i samtaler om behandling ved livets slutt med eldre pasienter, var å kartlegge sykepleiernes erfaringer med samtalene. Beskrivelser av slike erfaringer mangler i litteraturen, selv om behovet for å gi eldre pasienter mer autonomi er påtrengende. Vi valgte kvalitativ metode for oppgaven med allsidig analyse av intervjuutsagn. Med utgangspunkt i Etiske prinsipper for medisinsk forskning, kjent som Helsinki-deklarasjonen av 1964, har informantene godkjent at vi refererer til deres uttalelser i artikkelen.

\section{Resultater}

$\mathrm{Da}$ informasjonssamtalene ble satt i system i 


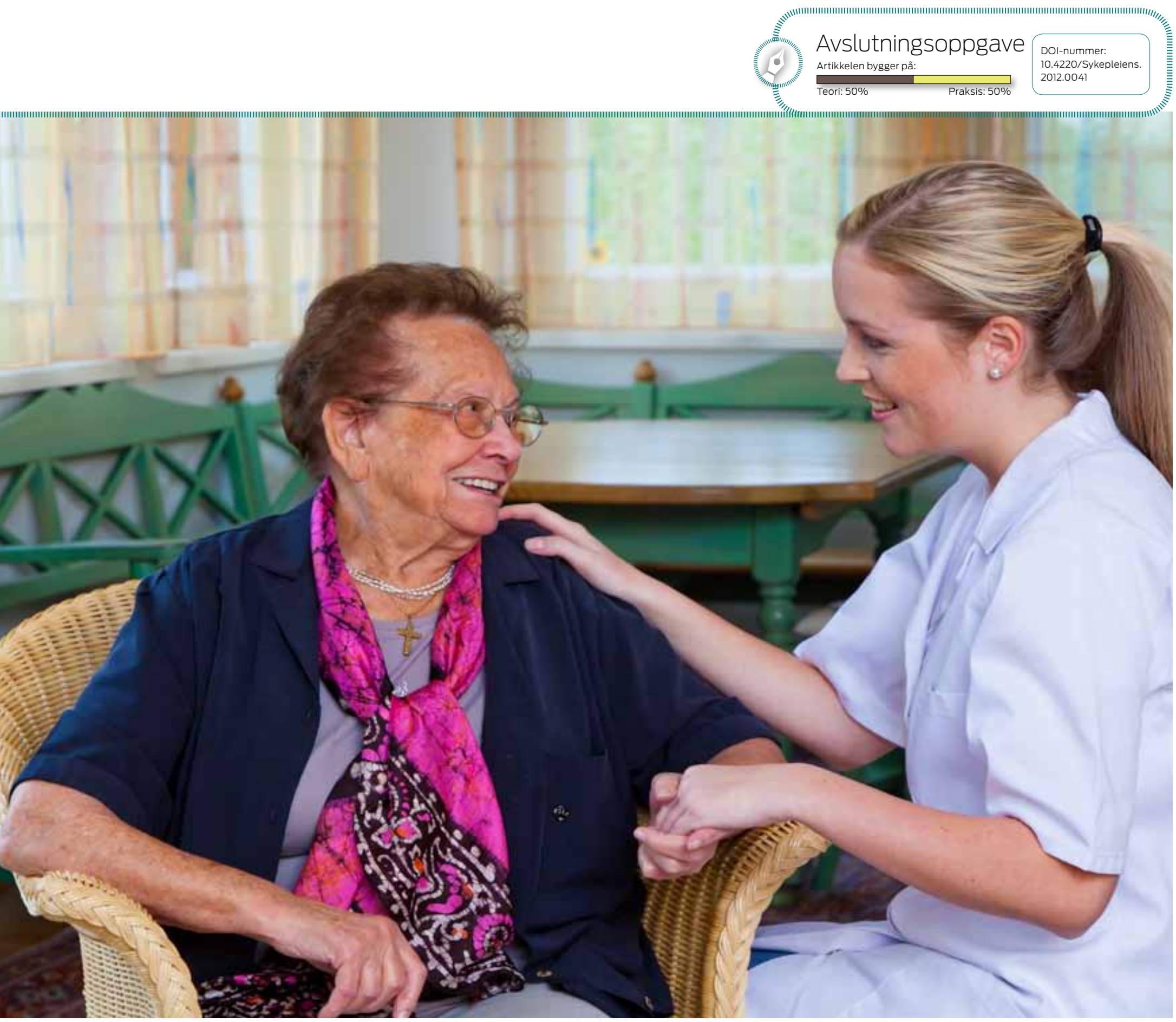

Sykepleiere på sykehjem som samtaler med eldre om livets siste fase, opplever å gi god omsorg. Illustrasjonsfoto: Colourbox.

2009, var sykepleierne skeptiske og utrygge: «I første samtale sa jeg ingenting, jeg syntes det var vanskelig ... Det var merkelig i begynnelsen, vi visste ikke hvordan pasientene ville reagere ...».

Men etter to år med informasjonssamtaler er sykepleiernes erfaringer preget av positiv respons både fra pasientene og pårørende: «Det er helt fantastisk, alt er blitt mye bedre nå etter at vi har begynt med samtalene. Vi har bare fått positive respons, det er bare fordeler for alle parter på alle måter ... pårørende sier at det var godt å få snakket om disse tingene, det er godt for sykepleiere også».

Sykepleierne hevder at det er blitt mindre unødvendige innleggelser på sykehus, mindre kontakt med legevakt, mer trygghet i behandlingssituasjonene og lite konflikter med pasienter og pårørende etter at informasjonssamtalene ble rutine. Også faglitteraturen (11) viser at tilpasset informasjon til familier til pasienter i livets sluttfase gir større trygghet for alle involverte og forebygger konfliktene.

\section{Sykepleiernes rolle}

Sykepleierne har vurdert sin rolle i beslutningsprosessen vedrørende behandling, på forskjellige måter. De arrangerer møter slik at det passer for alle involverte. De deltar i tverrfaglig samarbeid ved å gjøre seg kjent med pasienten og svare på spørsmål om observasjoner og pleie under samtalene. Sykepleierne vurderer fortlø- pende om beslutningene vedrørende behandling gjelder fortsatt, og arrangerer revurdering hvis det er hensiktsmessig. Sykepleierne anser det å beskytte pasientens autonome valg i forhold til behandling som sin viktige oppgave: «Jeg som sykepleier passer på å gjøre det slik pasienten ønsker. Det er derfor vi har disse samtalene. Jeg ville ha fått dårlig samvittighet hvis pasienten ble sendt på sykehus dersom han eller hun ikke ønsket det».

\section{Informasjon}

Sykepleierne har opplevd stemningen under samtalene som god og avslappet, og forholdene som uproblematiske: «... veldig god stemning under samtalene, det blir en god tone mellom 
oss, vi samarbeider veldig godt med pasienter og pårørende».

I samsvar med Pasientrettighetsloven (4) blir samtykkekompetente pasienter spurt om tillatelse til å gi informasjon til pårørende, og pårørende blir spurt om hvor mye informasjon de vil ha. Informasjonen som formidles inneholder valg i forhold til behandlingsalternativer, og hva sykehjemmet har å tilby. Ikke alle spørsmål blir tatt opp hvis pasienten viser tegn til stress. Denne holdningen er i samsvar med litteraturen, som presiserer at mer informasjon ikke automatisk betyr mer autonomi, og at informasjon ikke skal overstige pasientens evne til å akseptere den (11).

\section{God omsorg}

Sykepleierne erfarte at informasjonssamtalene innebærer god omsorg for pasienter og pårørende. Avklaring av behandlingsstrategier, spesielt i forhold til smertelindring, medvirket til økt trygghet og velbefinnende hos pasienter: «Vi så lettelse i ansiktene da de fikk beskjed om at de ikke skulle ha det vondt ved døden, at de skulle

\section{«Vi så lettelse i ansiktene da de fikk beskjed om at de ikke skulle ha det vondt ved døden.»}

få smertestillende. Opplevelse av trygghet kom veldig tydelig fram».

Sykepleierne har erfart at de ivaretar pasientenes autonomi gjennom informasjonssamtalene: «Vi ble mer bevisst på at vi gir mer autonomi til pasientene siden vi har begynt med samtalene, at vi ser dem ... vi spør først, pasienten setter pris på det. De har valg».

Med støtte i litteraturen $(11,12)$ og fra Helsedirektoratet (5) mener vi at respondentenes uttalelser, presentert her, bekrefter at informasjonssamtalene er autonomifremmende.

\section{Kan si nei}

Sykepleierne understreket at informasjonssamtale er et tilbud, som både pasienter og pårørende kan si nei til. I slike tilfeller blir pasienters eller pårørendes reservasjon mot samtale respektert. Hvis pasienten gir indirekte signaler om at de ikke ønsker samtalen, ved unnvikende atferd, blir dette også respektert. Denne stra- tegien gjelder også ved oppfølgingssamtale en gang i året. Denne framgangsmåten samsvarer med anbefalingene fra Helsedirektoratet (5) som fremhever autonomiprinsippet hvis pasienten reserverer seg fra å delta i informasjonssamtale.

\section{Pårørendes rolle}

Sykepleiernes positive erfaringer fra samarbeid med pårørende under informasjonssamtalene er i absolutt flertall og støttes av litteraturen (11): «Pårørende spiller en veldig positiv rolle, oppmuntrer pasienten. De spør pasienten; hva synes du? Jeg har aldri opplevd at pårørende har presset pasienten».

Det er en annen side ved pårørendes deltakelse i beslutningsprosessen vedrørende behandling, som er viktig å belyse. Sykepleierne presiserte at pårørende helst ikke vil ta bestemmelser om sensitive spørsmål: «Det er fryktelig vanskelig for pårørende å si - ikke gjenoppliv min mor, for eksempel. Selv om de kanskje tenker det, er det vanskelig å si det».

Sykepleierne mente at helsepersonellet bør ta hensyn til denne problemstillingen, og ikke belaste pårørende med ansvar for slike tunge avgjørelser. En slik holdning har støtte i Pasientrettighetsloven (4).

\section{Etiske utfordringer}

Noen hevder at en samtale om behandling ved livets slutt kan virke oppskakende på den eldre pasienten. Faglitteraturen avkrefter dette, og viser til at pasienter i terminalfasen oftest ønsker å vite sannheten om sin egen tilstand og fremtidsutsikt (12). Ved å føre åpne samtaler om utfordringene i nåtid og nær framtid med den eldre pasient og de pårørende, kan potensielle etiske konflikter forebygges, og de fleste etiske utfordringer løses (11).

På bakgrunn av dette mener sykepleierne på Lunde sykehjem at utfordringene i forbindelse med informasjonssamtalene er sjeldne og uansett oppveies av den nytten samtalene har. De opplevde enkelte situasjoner da pasient og pårørende var uenige om behandlingsopplegget eller hadde urealistiske forventninger til behandlingsmulighetene. I disse situasjonene var det den samtykkekompetente pasienten som bestemte over valget av behandlingen fremfor pårørende. Ved urealistiske forventninger forklarte legen og sykepleierne hva slags behandling pasienten kunne få.

\section{Faglig venighet}

Sykepleierne hadde delte meninger i forhold til hvilket tidspunkt det var best å innlede informasjonssamtale på, og når det var mest hensiktsmessig å ta opp spørsmålet om gjenoppliving. Helsedirektoratet (5) anbefaler å innlede informasjonssamtale med pasienten så snart pasienten flytter inn på en varig institusjon. I samsvar med dette mente de fleste sykepleierne som ble intervjuet at helsetilstanden til pasienter som flytter inn på institusjon ofte er ustabil, og at samtalen bør innledes snarest mulig mens pasienten er i stand til å formidle sine ønsker. Likevel hadde noen av sykepleierne sterke argumenter for å vente i noen uker, slik at man kunne bli bedre kjent både med pasienten og familieforholdene. På den måten hevdet de å kunne svare bedre på pasientens spørsmål under samtalen.

Det var faglig uenighet i forhold til det mest hensiktsmessige tidspunktet for spørsmålet om gjenoppliving. Noen av sykepleierne mente at dette spørsmålet kommer fram på en naturlig måte ved årlige oppdateringer av samtalene når helsetilstanden til pasienten forverrer seg. Imidlertid, ble det argumentert for fordelene ved å ta opp spørsmålet om gjenoppliving ved første samtale: «Ofte skjer det ting med de eldre pasientene som vi ikke regner med. Derfor vet vi aldri når pasienten blir dårlig og ikke lenger i stand til å si sin mening. Det er godt å snakke om gjenoppliving ved første samtale, de er ofte glad for at vi kommer med dette spørsmålet. Legen forklarer også om det har noen hensikt med gjenoppliving i forhold til de sykdommene pasienten har».

Sykepleierne opplyste at de hadde hatt gode erfaringer med sine strategier, både i forhold til spørsmålet om gjenoppliving og vedrørende det mest hensiktsmessige tidspunktet for informasjonssamtale. Dette til tross for at strategiene ofte var ulike.

\section{Rutiner for samtale}

Pasienter får tilbud om samtale og blir spurt om de ønsker at pårørende skal være med. Samtalene arrangeres på dagtid. Legen og den sykepleieren som kjenner pasienten best, er alltid til stede under samtalen. De avgjørelsene som blir tatt, føres inn i skjemaet og blir oppbevart i permen. Informasjonen blir også lagret elektronisk både av lege og sykepleier. Oppfølgingssamtalene blir rutinemessig planlagt en gang i året. Men samtalene kan også finne sted på kort varsel, hvis det skjer en forandring i helsetilstanden til pasienten som krever revurdering av behandlingsplanen. Det blir også i stor utstrek- 
ning tilbudt kommunikasjon og informasjon utenom samtalene.

\section{Konklusjon}

Sykepleierne, som rutinemessig deltar i informasjonssamtalene vedrørende sykehjemsbeboeres preferanser i forhold til behandling ved livets slutt, definerer sine erfaringer som absolutt positive. De opplever denne type samtaler som god omsorg både for pasienter og pårørende. Informasjonssamtalen, som inkluderer tilbud om valgmuligheter for behandlingen ved livets slutt, fremmer pasientens autonomi og velbefinnende. Samtalen skaper trygghet i behandlingssituasjoner både for pasienter, pårørende og helsepersonellet. De etiske utfordringene, som sykepleierne uttalte at de had- de opplevd i noen få situasjoner, oppveies av nytten samtalene har. Til tross for forskjellig praksis når det gjelder tidspunktet for informasjonssamtale og avklaring av spørsmålet om gjenoppliving, har sykepleierne opplevd sine strategier som suksessfulle. Dette kan tyde på at faglig innsikt har en avgjørende betydning i den konkrete situasjonen. Mer forskning er nødvendig for å oppklare dette spørsmålet. Det er viktig med gode og faste rutiner ved informasjonssamtalene. Med støtte i faglitteraturen og de positive funnene intervjuene med sykepleierne har avdekket, mener vi at samtale med eldre pasienter på sykehjem om behandling ved livets slutt er autonomifremmende for og kan anbefales på sykehjem som god omsorg. IIII

\section{LITTERATUR}

1. De Gendt C, m.fl. Prevalence of patients with do-not-resuscitate status on acute geriatric wards in Flanders, Belgium. Journals of Gerontology Series A 2007; Apr; 62A:395-9.

2. McCarthy FP, m.fl. Advance care planning and health preferences of community-dwelling elders. Journals of Gerontology Series A 2008; Sep; 63A:951-9.

3. Dreyer A, Førde R, Nortvedt P. Life-prolonging treatment in nursing homes: how do physicians and nurses describe and justify their own practice? J Medical Ethics 2010; 36:396-400.

Lov om pasientrettigheter 1999-07-02 nr. 63. I teksten: Pasientrettighetsloven

5. Helsedirektoratet. Nasjonal veileder for beslutningsprosesser for begrensning av livsforlengende behandling hos alvorlig syke og døende. 0slo: 2009 .

6. Stortingsmelding nr. 25. Helse- og omsorgsdep.. 2005-2006.

7. WHO. Health and Human Rights Working Paper Series No 2 (2003). http://www.int/hhr/information/papers/en/index.html

$\mathrm{http}: / /$ www.int/hhr/information/papers/en/index.html
Yrkesetiske retningslinjer for sykepleiere, 2007. http://www.sykepleier8. Yrkesetiske rethin

Nasjonal helseplan 2007-2010. Helse- og omsorgsdepartementet.

10. Bondevik M. Pleie og omsorg mot livets slutt. I: Bondevik M, Nygaard HA. Tverffaglig geriatri. En innføring. Bergen: Fagbokforlaget, 2008: 145-151.

11. Husebø B, Husebø S. De gamles siste timer og dager. I: Bondevik M, Nygaard HA. Tverrfaglig geriatri. En innføring. Bergen: Fagbokforlaget, 2008: 306-315.

12. Daatland SO, Solem PF. Aldring og samfunn. En innføring i sosialgerontologi. Bergen: Fagbokforlaget, 2007.

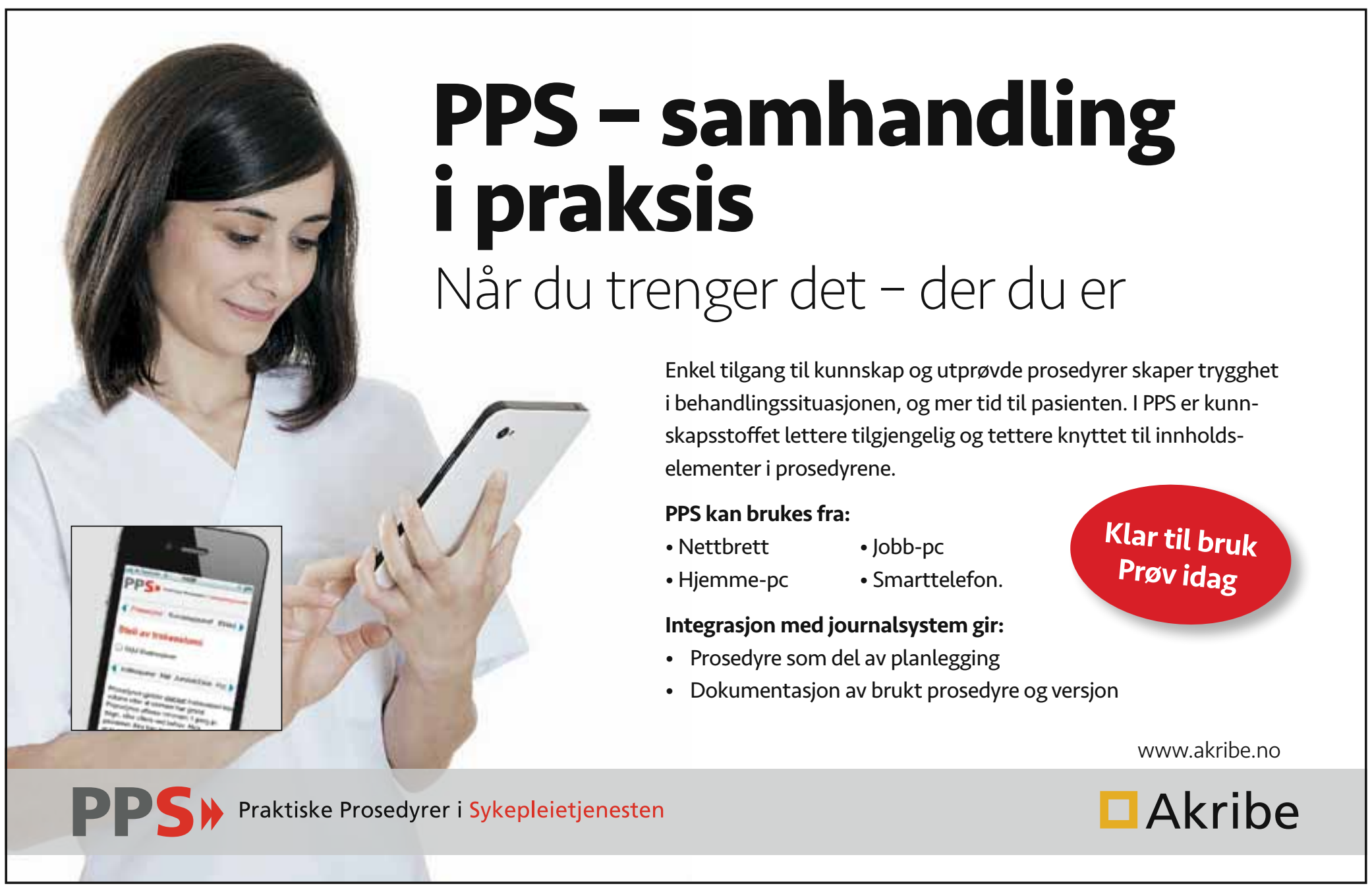

